This is the author's manuscript for publication. The publisher-formatted version may be available through the publisher's web site or your institution's library.

\title{
Effect of the Programmed Nutrition Beef Program on moisture retention of cooked ground beef patties and enhanced strip loins
}

K. J. Phelps, J. S. Drouillard, J. S. Jennings, B. E. Depenbusch, M. A. Vaughn, D. D. Burnett, S. M. Ebarb, G. J. Dietz, J. D. Heitschmidt, J. A. Noel, T. A. Houser and J. M. Gonzalez

\section{How to cite this manuscript}

If you make reference to this version of the manuscript, use the following information:

Phelps, K. J., Drouillard, J. S., Jennings, J. S., Depenbusch, B. E., Vaughn, M. A., Burnett, D. D., ... Gonzalez, J. M. (2015). Effect of the Programmed Nutrition Beef Program on moisture retention of cooked ground beef patties and enhanced strip loins. Retrieved from http://krex.ksu.edu

\section{Published Version Information}

Citation: Phelps, K. J., Drouillard, J. S., Jennings, J. S., Depenbusch, B. E., Vaughn, M. A., Burnett, D. D., ... Gonzalez, J. M. (2015). Effect of the Programmed Nutrition Beef Program on moisture retention of cooked ground beef patties and enhanced strip loins. Meat Science, 100, 189-194.

Copyright: (c) 2014 Elsevier Ltd.

Digital Object Identifier (DOI): doi:10.1016/j.meatsci.2014.10.021

Publisher's Link: http://www.sciencedirect.com/science/article/pii/S0309174014004690

This item was retrieved from the K-State Research Exchange (K-REx), the institutional repository of Kansas State University. K-REx is available at http://krex.ksu.edu 
2 Effect of the Programmed Nutrition Beef Program on moisture retention of cooked ground beef patties and enhanced strip loins ${ }^{1,2}$

$4 \quad$ K. J. Phelps*, J. S. Drouillard*, J. S. Jennings ${ }^{\dagger}$, B.E. Depenbusch ${ }^{\ddagger}$, M. A. Vaughn*, D. D. 5 Burnett*, S. M. Ebarb*, G. J. Dietz*, J. D. Heitschmidt*, J. A. Noel, T. A. Houser* and J. M. Gonzalez*3

$7 \quad *$ Kansas State University, Dept. of Animal Sciences and Industry, Manhattan 66506; ${ }^{\dagger}$ Alltech, 8 Inc., Nicholasville, KY 40356; ${ }^{+}$Innovative Livestock Services, Great Bend, KS 67530

${ }^{1}$ This project was supported by Alltech, Inc.

$11{ }^{2}$ Contribution no. 14-252-J of the Kansas Agricultural Experiment Station, Manhattan 66506

$12 \quad{ }^{3}$ Corresponding author: johngonz@k-state.edu

13 


\section{ABSTRACT:}

16 This study evaluated the influence of the Programmed Nutrition Beef Program and exogenous

17 growth promotants (ExGP) on water holding capacity characteristics of enhanced beef strip

18 loins. Sixty, frozen strip loins, arranged in a $2 \times 2$ factorial treatment arrangement with dietary

19 program serving as the first factor and use of ExGP as the second factor, were thawed, injected

20 with an enhancement solution, and stored for $7 \mathrm{~d}$. Loins from ExGP cattle possessed the ability

21 to bind more $(P<0.05)$ water before pumping and bind less $(P<0.05)$ water after pumping and

22 storage. Loin $\mathrm{pH}$ across treatments was similar $(P>0.10)$ before injection, but increased post-

23 injection and after storage $(P<0.01)$. Treatments did not affect loin purge loss, steak cook loss,

24 and expressible moisture $(P>0.10)$. The Programmed Nutrition Beef Program and use of ExGPs

25 minimally impacted water holding capacity of enhanced frozen/thawed beef strip loins.

26 Keywords: Water-holding; Beef; Ractopamine; Feeding, Enhancement 


\section{Introduction}

The goal of the beef industry is to produce a consistent, high quality product as efficiently

29 as possible. Many different feedlot management strategies are employed to maximize efficiency including the utilization of different feed additives such as monensin (Rumensin; Elanco Animal Health, Greenfield IN) and tylosin (Tylan; Elanco Animal Health), and growth promoting technologies such as beta-adrenergic agonists and steroidal implants. Utilization of feed additives, implants, and beta-adrenergic agonists can greatly improve efficiency of beef production, but also can have negative consequences for beef quality (Winterholler et al., 2008). Beef palatability encompasses characteristics such as juiciness, tenderness, and flavor (Platter, Tatum, Belk, Scanga, \& Smith, 2003), but water-holding capacity also impacts beef palatability. The ability of whole muscle or ground beef to retain moisture during storage and through processing is an important quality characteristic. It is established moisture loss from whole muscle products can impact the amount of salable product (Offer et al., 1989; Huff-Lonergan and Lonergan, 2005). Although cook yields of ground beef can be mostly dependent on fat content of the blend (Roth, McKeith, \& Brewer, 1999), the ability of product to retain water during processing and cooking could also be important.

The Programmed Nutrition Beef Program (Alltech Inc., Nicholasville, KY) consists of two products that are designed to replace components of conventional feedlot diets. The Programmed Nutrition Beef Receiver is intended to be fed during the step-up period at the rate of $14 \mathrm{~g} \bullet a n i m a l^{-1} \bullet \mathrm{d}^{-1}$, while Programmed Nutrition Beef Finisher is fed for the remainder of the finishing period at a rate of $20 \mathrm{~g} \bullet \mathrm{animal}^{-1} \bullet \mathrm{d}^{-1}$. Previous research by Phelps et al. (2014) reported the use of Programmed Nutrition Beef Program supplements in finishing feedlot diets decreased purge loss of strip loins aged $14 \mathrm{~d}$ compared to strip loins from steers fed a diet containing 
conventional feedlot dietary components. Additionally, steaks from steers fed the Programmed

51 Nutrition Beef Program supplements and steaks from steers that were not administered

52 exogenous growth promotants (ExGP) had a decreased cook loss when compared to steaks from

53 the conventional feedlot diet and administered ExGP, respectively. The objectives of this study

54 were to evaluate influence of the Programmed Nutrition Beef Program and ExGPs on moisture

55 retention of $85 \%$ lean ground beef patties, brine uptake and retention, objective water holding

56 capacity, and Warner-Bratzler shear force (WBSF) of strip loins that were thawed from a frozen

57 state and enhanced $110 \%$ with a salt/tripolyphosphate solution.

\section{Materials and Methods}

59

60

61

62

\subsection{Animals}

Crossbred feedlot steers (initial BW $383 \mathrm{~kg} \pm 30 ; n=64$ pens; 16 pens/treatment; 8 steers/pen) were blocked by body weight and subjected to a randomized complete block design with $2 \times 2$ factorial treatment arrangement. Steers were separated into a conventional finishing program treatment $(\mathbf{C O N})$ or Alltech Programmed Nutrition Beef Program treatment (PN; Table 1). Conventional diets contained monensin, tylosin, vitamins $A$ and $E$, and supplemented trace minerals including copper sulfate, cobalt carbonate, ethlenediamine dihydriodide, manganous sulfate sodium selenite, and zinc sulfate. The Programmed Nutrition Beef Receiver portion of the diet was included in the total mixed ration for the first $21 \mathrm{~d}$ at a rate of $14 \mathrm{~g} \bullet$ animal $^{-1} \bullet \mathrm{d}^{-1}$. The Programmed Nutrition Beef Finisher was included in the total mixed ration at a rate of 20 $\mathrm{g} \bullet$ animal ${ }^{-1} \cdot \mathrm{d}^{-1}$ for the final $154 \mathrm{~d}$ of the feeding period. The components of the Alltech Programmed Nutrition Beef Program diet were premixed into a ground corn carrier and subsequently blended into the total mixed ration. Both the Programmed Nutrition Beef Receiver and Finisher supplements contained a proprietary blend of organic trace elements, ascorbic acid, 
73 Lactobacillus acidophilus fermentation product, Enterococcus faecium fermentation product, and

74 selenium yeast. Additionally, Programmed Nutrition Beef Receiver included Aspergillus niger

75 fermentation extract and Programmed Nutrition Beef Finisher included Aspergillus oryzae

76 fermentation extract. Each diet was fed in conjunction with (EGP+) or in the absence of (EGP-)

77 exogenous growth promotants (ExGP). Steers receiving ExGP were administered a Component

78 E-S implant on d 1 of the study, reimplanted with Component TE-IS (Elanco Animal Health) on

$79 \mathrm{~d}$ 94, and fed ractopamine hydrochloride (RAC; Elanco Animal Health) at a rate of $400 \bullet \mathrm{d}^{-}$

$80{ }^{1} \cdot$ steer $^{-1}$ the final $28 \mathrm{~d}$ before harvest.

812.2 Loin collection

On d 175 of the study, animals were shipped $430 \mathrm{~km}$ to a commercial abattoir (Tyson

83 Fresh Meats, Holcomb, KS) for harvest. After a 36-h chill, strip loins (Institutional Meat

84 Purchase Specifications 180) were removed from the left side of 2 carcasses selected at random

85 from each pen and were transported back to the Kansas State University Meats Laboratory.

86 Loins were wet-aged for $14 \mathrm{~d}, 5$ steaks were fabricated from the anterior portion of the

87 Longissimus lumborum for another study (Phelps et al., 2014), and the remainder of the

88 Longissimus lumborum was frozen at $-40^{\circ} \mathrm{C}$.

$89 \quad 2.3$ Loin Selection and Sampling

The posterior portion of the Longissimus lumborum of sixty frozen beef strip loins $(\mathrm{n}=$

9115 per treatment) were selected at random from the previous study (Phelps et al., 2014). For the

92 injection study, loins selected were large enough to be injected (smallest loin $=0.58 \mathrm{~kg}$ ), and also

93 yielded $500 \mathrm{~g}$ of tissue for grinding. This resulted in a sample distribution that represented all 16

94 of the original weight blocks and 52 of the pens of the Phelps et al. (2014) study. 
Forty-eight hours prior to processing, strip loins were removed from the freezer and

97 thawed at $2 \pm 1^{\circ} \mathrm{C}$. Once thawed, all subcutaneous fat was removed from each loin, identified

98 by loin number, and reserved for subsequent preparation of ground beef patties. From each

99

100

101

102

103

104

105

106

107

108

109

110

111

112 from packages, patted dry, and re-weighed for purge loss calculations [(injected weight-stored trimmed loin, approximately $500 \mathrm{~g}$ of muscle was removed for grinding from the most anterior portion of each loin. Additionally, a 120-g sample was removed for measurement of expressible moisture (EM) and water binding ability (WBA) as described below. Before injection, pH was measured using a pH probe designed for use in meat (Model HI 99163; Hanna Instruments, Smithfield, RI) and loin sections were weighed. Loin sections were injected using a multi-needle injector (Model N50: Schröder Maschinenbau GmbH, Werther, Germany) with a brine solution (pH 7.95) which contained 5\% sodium chloride and 3\% sodium tripolyphosphate (Brifisol 85 Instant; BK Giulini Corp., Simi Valley, CA) to achieve a $0.5 \%$ sodium chloride and $0.3 \%$ sodium tripolyphosphate level within the muscle when pumped $10 \%$ over green weight. Following a 2-min rest period, loins were reweighed to ensure brine was assimilated to achieve $110 \%$ above green weight (average $111.14 \pm 1.46 \%$ ) and $\mathrm{pH}$ was recorded again before injected loins were vacuum packaged in 3-mm high-barrier vacuum pouches (Prime Source, Bunzyl Processor Division, Kansas City, MO). After storage for $7 \mathrm{~d}$ at $2 \pm 1{ }^{\circ} \mathrm{C}$, loins were removed

113 weight)/injected weight] $\times 100$. At this time, $\mathrm{pH}$ was measured, a 120-g sample was removed for 114 expressible moisture and WBA analyses, and a 2.54-cm thick steak was fabricated for 115 determination of WBSF.

\subsection{Grinding}

To formulate a ground beef blend that was $85 \%$ lean and $15 \%$ fat, analyzed fat 118 percentages from proximate analysis were used to calculate a blend for each sample. Using a 
119 table top grinder (Model KG-12-FS; Pro-Cut, Houston, TX), lean and fat for each sample were

120 ground separately through a $9.5-\mathrm{mm}$ plate, blended together by hand, and then reground through

121 a 3.2-mm plate. Once ground, two $1.2-\mathrm{cm}$ thick $\times 10.7-\mathrm{cm}$ wide patties weighing $112 \mathrm{~g}$ were

122 formed from each sample.

123 2.6 Cooking and Warner-Bratzler shear force

124

125

126

127

128

129

130

131

132

133

134

135

136

137

138

139

140

All cooking and WBSF procedures were conducted according to the Meat Cookery and Sensory Guidelines (AMSA, 1995). Ground beef patties were weighed before cooking and cooked on a flat top grill (Model 106733; Walmart, Bentonville, AR) set to $132^{\circ} \mathrm{C}$. Patties were turned at $1 \mathrm{~min}$, turned again at $2 \mathrm{~min}$, and then turned every 2 min until they reached an internal temperature of $71^{\circ} \mathrm{C}$. A hypodermic needle thermometer consisting of a copper-constantan probe connected to a Doric Trendicator 410A monitor (VAS Engineering; San Francisco, CA) was used to monitor internal temperature. Patties were cooled at room temperature and once they could be handled they were reweighed to determine cook loss [(precooked weight-cooked weight)/precooked weight] $\times 100$.

Prior to cooking, steaks were weighed and a thermocouple wire (30-gauge copperconstantan; Omega Engineering, Stamford, CT) was inserted into the geometric center of each steak to monitor internal temperature using a Doric Minitrend 205 monitor (VAS Engineering). Steaks were cooked on electric, open-hearth Hamilton Beach grills (Indoor/Outdoor; Southern Pines, NC) preheated to $204^{\circ} \mathrm{C}$. Steaks were turned when they reached an internal temperature of $40{ }^{\circ} \mathrm{C}$, removed from grills at $70{ }^{\circ} \mathrm{C}$, and allowed to cool until they could be handled before being reweighed to determine cook loss [(precooked weight-cooked weight)/precooked weight] $\times 100$. Steaks were chilled for $24 \mathrm{~h}$ at $7 \pm 1{ }^{\circ} \mathrm{C}$, and six $1.27-\mathrm{cm}$ cores were then removed from 
141 each steak parallel to the muscle fiber. Cores were sheared once through the center using an

142 INSTRON Model 5569 testing machine (Instron, Canton, MA) with a Warner-Bratzler shear

143 head attached (100-kg compression load cell, crosshead speed of $250 \mathrm{~mm} / \mathrm{min}$ ).

\section{$144 \quad 2.7$ Water binding ability and expressible moisture}

The WBA of samples was measured by protein swelling analysis as described by

146 Pietrasik and Janz (2009) with a modification. The modification made was the 100-g sample of

147 muscle was cut into $0.5 \times 0.5 \times 0.5 \mathrm{~cm}$ pieces and then blended in a Waring blender (Waring

148 Products Division, Hartford, CT) with $300 \mathrm{~mL}$ of distilled water. The remainder of the procedure 149 was carried out as described by the authors.

Expressible moisture of samples was measured using the centrifugation method described

151 by Jauregui, Regenstein, and Baker (1981). A 5-g sample of muscle was weighed, placed in a 50

$152 \mathrm{~mL}$ conical tube on top of $25 \mathrm{~g}$ of $4-\mathrm{mm}$ glass beads, and centrifuged at $900 \times g$ for $10 \mathrm{~min}$. After

153 centrifugation, samples were removed from tubes and reweighed. Percent EM was calculated as

154 [(initial weight-centrifuged weight)/initial weight] $\times 100$.

1552.8 Statistical analyses

156 Purge loss, cook loss, and WBSF data were analyzed as a randomized complete block

157 design with a $2 \times 2$ factorial arrangement. Dietary program and ExGP served as the main effects

158 and the animal weight block from Phelps et al. (2014) was the random effect. For loin pH,

159 expressible moisture, and WBA, data were analyzed as repeated measures using a randomized

160 complete block design with a $2 \times 2$ factorial treatment arrangement. Period served as the

161 repeated measure with loin (observational unit) as the subject and compound symmetry as

162 covariance structure. The PROC MIXED procedure of SAS (SAS Inst. Inc., Cary, NC) was 
163 utilized and pair-wise comparisons between the least-squares means of the factor levels were 164 computed using the PDIFF option of the LSMEANS statement. Differences were considered 165 significant at $\alpha \leq 0.05$ and tendencies at $\alpha \leq 0.10$.

166

167

\section{Results}

\subsection{Loin $p H$}

Loin $\mathrm{pH}$ was recorded at three periods: before injection, after injection, and after 7-d of storage post injection (Table 2$)$. There was no three-way interaction $(P=0.55)$ of dietary program $\times$ ExGP $\times$ period for $\mathrm{pH}$. Also, the two-way interaction of dietary program $\times$ ExGP did not affect $(P=0.39)$ loin $\mathrm{pH}$, but there was a tendency $(P=0.10)$ for a dietary program $\times$ period interaction to affect loin $\mathrm{pH}$. Pre-injection, the $\mathrm{pH}$ of $\mathrm{CON}$ and $\mathrm{PN}$ loins was similar $(P=0.75)$, but post-injection $\mathrm{PN}$ loins had a greater $(P=0.002) \mathrm{pH}$ than $\mathrm{CON}$ loins. Additionally, the postinjection $\mathrm{pH}$ of loins from both $\mathrm{CON}$ and $\mathrm{PN}$ loins increased $(P<0.01)$ by 0.37 and 0.32 units compared to their pre-injection $\mathrm{pH}$, respectively. The $\mathrm{pH}$ recorded for both dietary treatments after $7 \mathrm{~d}$ of storage was similar to that recorded post-injection $(P>0.15)$; however, there was no difference $(P=0.50)$ in $\mathrm{pH}$ between the two dietary treatments after $7 \mathrm{~d}$ of storage. Also, $\mathrm{pH}$ data indicate an ExGP $\times$ period interaction $(P=0.02)$. Pre-injection $\mathrm{pH}$ was $\operatorname{similar}(P=0.88)$ between EGP+ and EGP- loins. Post-injection pH of EGP- loins was greater $(P=0.001)$ than EGP+ loins, but $\mathrm{pH}$ recorded after 7 -d of storage was similar $(P=0.89)$ between the two treatments. The $\mathrm{pH}$ of loins from the two dietary treatments differed with $\mathrm{PN}$ loins having a $\mathrm{pH}$ that was 0.04 units greater $(P=0.02)$ than $\mathrm{CON}$ loins. Additionally, there was a tendency $(P=$ 0.052) for $\mathrm{pH}$ difference between the two ExGP treatments. Finally, as expected, period elicited an effect $(P<0.01)$ on the $\mathrm{pH}$ of loins. Before injection, the $\mathrm{pH}$ of loins was 5.53 , and post- 
185 injection $\mathrm{pH}$ was 0.32 units greater $(P<0.01)$. The $\mathrm{pH}$ recorded after $7 \mathrm{~d}$ of storage was

186 comparable $(P=0.77)$ to post-injection $\mathrm{pH}$.

3.2 Purge loss, cook loss, and WBSF

188

189

190

191

192

193

194

195

196

197

198

199

200

201

202

203

204

205
For purge loss, steak cook loss, and ground beef cook loss there was no two-way interaction of dietary program $\times \operatorname{ExGP}($ Table $3 ; P>0.34)$. Also, the main effect of dietary program did not affect purge loss, steak cook loss, and ground beef cook loss $(P>0.35)$. Additionally, the ExGP effect did not impact purge loss or steak cook loss $(P>0.23)$, but there was a tendency $(P=0.08)$ for ExGP use to affect ground beef cook loss with ground beef patties from the EGP- tending to have a cook loss $1.06 \%$ greater than the EGP+ treatment.

Warner-Bratzler shear force was measured on strip loin steaks fabricated from enhanced loins (Table 3$)$. There was a tendency $(P=0.06)$ for a dietary program $\times$ ExGP interaction to affect shear force. Dietary program influenced $(P=0.05)$ WBSF of steaks from enhanced loins. The shear force of steaks from PN loins was $0.15 \mathrm{~kg}$ less $(P=0.05)$ than the shear force of steaks from CON loins. The use of ExGP during the finishing phase did not impact $(P=0.54)$ shear force of steaks fabricated from enhanced loins.

\subsection{Expressible moisture and water binding ability}

There was no dietary program $\times$ ExGP $\times$ period interaction for EM or WBA (Table 4; $P$ $>0.36)$. The two-way interactions of dietary program $\times$ ExGP or dietary program $\times$ period did not affect EM or WBA (Table 5; $P>0.84)$. The ExGP $\times$ period interaction did not impact $(P=$ $0.13)$ EM, but did influence WBA $(P<0.01)$. Before injection, EGP+ loins had greater $(P=$ 0.01) WBA compared to EGP- loins. After loins were injected and stored EGP- loins had a 
greater $(P<0.01)$ WBA than EGP+ loins. Finally, the main effects of dietary program and ExGP did not impact EM or WBA $(P>0.21)$.

\section{Discussion}

Beef palatability is influenced by many attributes, including tenderness, marbling, texture, juiciness, and flavor profile (Miller, Carr, Ramsey, Crockett, \& Hoover, 2001). These attributes can be influenced by a wide range of factors, including genetics, age, diet, pre-harvest management, and post-mortem processing (Hocquette, et al., 2012). Although the amount of marbling often influences juiciness the most (O'Quinn et al., 2011), water holding capacity of beef may also play a role in a consumer's beef eating experience (Winger \& Hagyard, 1994). Intrafiber water content has been suggested to impact meat tenderness (Currie \&Wolfe, 1980) and could potentially impact overall palatability of beef. In addition to influencing palatability, poor water holding capacity of products can result in loss of salable weight for processors and retailers (Huff-Lonergan and Lonergan, 2005).

Water holding capacity of beef and other meat products is largely influenced by $\mathrm{pH}$ (Honikel, 2004). When meat reaches its isoelectric point the net charge of proteins is zero. This effectively decreases the amount of water held between proteins as a result of the close association between positively and negatively charged protein moieties. When the $\mathrm{pH}$ of meat is transitioned away from its isoelectric point, water holding capacity improves (Aberle et al., 2003). The increase in meat $\mathrm{pH}$ following the use of phosphates in brine solutions is well documented (Smith, Simmon, McKeith, Bechtel, \& Brady, 1984; Robbins et al., 2002; Wicklund et al., 2005). In the present study, the common increase in $\mathrm{pH}$ due to brine injection was duplicated. Loin $\mathrm{pH}$ recorded post-injection and after $7 \mathrm{~d}$ of storage were increased by 0.32 and 
$0.33 \mathrm{pH}$ values, respectively when compared to $\mathrm{pH}$ recorded prior to injection. Similar to the

229 present study, Wicklund et al. (2005) reported increases in muscle pH (0.32 units) when beef

230 strip steaks were enhanced with a brine containing phosphates. Pietrasisk and Janz (2009)

231 reported a smaller $\mathrm{pH}$ increase of 0.23 units in enhanced beef Semitendinosus steaks compared to

232 non-enhanced steaks, while Robbins et al. (2002) observed that $\mathrm{pH}$ values of enhanced beef

233 rounds were 0.28 units greater compared to non-enhanced rounds. Finally, Grobbel, Dikeman,

234 Hunt, \& Milliken (2008) reported that $\mathrm{pH}$ of enhanced Longissimus, Semitendinosus, and Triceps

235 brachii steaks were $0.3,0.2$, and 0.2 units higher, respectively, compared to non-enhanced

236 steaks. The current data also indicate that the ExGP $\times$ period interaction, dietary treatment, and

237 ExGP treatment affected $\mathrm{pH}$. When examining the differences closely, the differences in $\mathrm{pH}$ are

238 all less than 0.10 , which presumably would have a relatively small biological effect on water

239 holding characteristics. Therefore, any treatment differences in water binding characteristics,

240 cook loss, WBSF post-injection and storage occurred independent of $\mathrm{pH}$.

Water binding ability measures the capacity of muscle to assimilate and retain additional

242 water. In the current study, the WBA of EGP+ loins was greater than EGP- loins prior to

243 enhancement and storage. After enhancement, WBA of EGP+ loins were less than EGP- loins.

244 Because there were no differences in purge loss, the WBA data may indicate EGP+ were

245 incapable of retaining additional moisture after they were enhanced 110\%. Pietrasik and Janz

246 (2009) found that freezing greatly reduced the WBA of meat and injection with a $1.5 \%$

247 phosphate solution increased WBA over injection with a $0.5 \%$ phosphate solution. Since all meat

248 was frozen and the same brine solution was utilized on all loins, these factors can be eliminated

249 as contributing to the ExGP difference. It is feasible that increased WBA of EGP+ loins was due

250 to an increase in cross-sectional areas of type IIA and type IIX fibers as reported by Phelps et al. 
251 (2014). Offer and Trinick (1983) stated that the majority of water present in meat is located

252 within myofibrils, and these authors demonstrated that the degree of swelling by myofibrils

253 observed after injecting brine solution was similar to the amount of water retained by the muscle.

254 Therefore, since EGP+ loins possessed greater muscle fiber cross-sectional area as reported by

255 Phelps et al. (2014), they likely possessed more myofibrils with which to bind the brine solution.

257 supplemented steers had less purge loss during storage and also lost less weight during cooking 258 compared to their CON counterparts. Additionally, the authors observed similar moisture 259 retention properties for loins from cattle produced without ExGPs compared to those from cattle 260 produced with ExGPs. The moisture retention advantages observed by Phelps et al. (2014) were 261 expected to be duplicated in the meat systems examined in the present study. Data in this study 262 indicate that when loins from all pre-harvest treatments were subjected to needle-injection 263 enhancement, there are no differences in purge loss or cook loss. Numerous studies indicate that 264 enhancement of fresh meat can affect both purge loss and weight loss during cooking. In a study 265 in which purge loss was compared between non-enhanced and enhanced beef and bison steaks, 266 Pietrasik, Dhanda, Shand, and Pegg (2006) reported that enhanced steaks lost $0.97 \%$ more purge 267 than non-enhanced steaks. In contrast, Pietrasik and Janz (2009) reported that enhanced 268 Semitendinosus steaks lost less purge than non-enhanced samples. McGee, Henry, Brooks, Ray, $269 \&$ Morgan (2003) reported that injecting beef round roasts with a brine decreased weight loss 270 during cooking by $7.65 \%$ compared to non-injected controls, while Pietrasik and Shand (2005) 271 reported injection of Semimembranosus roasts decreased weight loss during cooking by $11.9 \%$. 
274 thawing of the loins prior to enhancement. Expressible moisture, which is greatly related to

275 moisture retention during storage and cooking, was unaffected by treatment before or after

276 enhancement. This could indicate that freezing/thawing may have masked the fresh meat

277 treatment related differences in moisture retention properties that were observed by Phelps et al.

278 (2014). Boles and Swan (2002) reported that beef inside rounds that were frozen prior to

279 injection retained $1 \%$ more brine solution than fresh injected rounds. The authors concluded that 280 the disruption of the protein structure due to freezing (Polymendis, 1978) allowed for increased 281 brine uptake. Pietrasik and Janz (2009) found that when frozen/thawed meat was stored $7 \mathrm{~d}$ post282 injection, expressible moisture was drastically improved when compared to frozen/thawed meat 283 stored $1 \mathrm{~d}$ post injection. Since Phelps et al. (2014) did not measure expressible moisture prior to 284 freezing, it is impossible to determine the effect of freezing/thawing on this water holding 285 characteristic. Enhancement of beef cuts with brine solutions has become a more common production 287 practice to alleviate tenderness issues (McGee et al., 2003). Regardless of treatment, average 288 reduction in shear force compared to Phelps et al. (2014) reported values were $13.0 \mathrm{~N}$ for all 289 steaks. Although it must be acknowledged the reduction in shear force of the enhanced steaks 290 may also be a function of freezing. Robbins et al. (2002) reported shear force of enhanced 291 Semimembranosus steaks was $0.52 \mathrm{~kg}$ lower than non-enhanced controls. In a study on the 292 enhancement of beef chuck muscles, Molina, Johnson, West, \& Gwartney (2005) found needle 293 injection reduced WBSF of oven-roasted Complexus and Subscapularis steaks and grilled 294 Triceps brachii steaks compared to non-injected controls by 11.7, 12.7, and 9.9 N, respectively. 295 Also, Grobbel et al. (2008) examined the enhancement of Longissimus lumborum, 296 Semitendinosus, and Triceps brachii steaks and reported needle injection decreased WBSF by 
$1.73,1.25$, and $1.25 \mathrm{~kg}$, respectively compared to non-injected controls. In contrast to the results

298

299

300

301

302 of Phelps et al. (2014), the data in the present study indicated that enhanced CON steaks were 1.5 N more tender than enhanced PN steaks. Miller et al. (2001) reported that consumers can distinguish between tenderness classifications at WBSF values of $0.30 \mathrm{~kg}$, suggesting that differences in tenderness between the enhanced $\mathrm{CON}$ and $\mathrm{PN}$ within the present study are unlikely to be detectable by consumers.

The greatest improvement in shear force from the Phelps et al. (2014) values due to enhancement was seen in EGP+ steaks, but there were no shear force differences for pre-harvest use of ExGP versus not using ExGP when loins were enhanced. Enhancement reduced the shear force of EGP+ by $15.2 \mathrm{~N}$ compared to values reported by Phelps et al. (2014). Brooks et al. (2010) reported enhancement of strip loins from cattle fed zilpaterol hydrochloride reduced shear force by $0.27 \mathrm{~kg}$. The greater reduction in shear force in the present study compared to Brooks et al. (2010) may have been influenced by freezing and thawing of loins prior to enhancement. As stated before, ice crystals formed during freezing can disrupt protein structure. Two studies (Hiner, Madsen, \& Hankins, 1945; Shanks, Wulf, \& Maddock, 2002) report lower WBSF of steaks frozen prior to cooking compared to steaks cooked fresh. The combined effects of moisture enhancement and freezing may have caused a much greater reduction in shear force.

Since Phelps et al. (2014) detected differences in fresh steak cook loss due to dietary program or ExGP use, effect of treatments on cook loss from ground beef patties was examined. In contrast to the fresh steak data, there were no differences in moisture loss during cooking of ground beef patties. Two mechanisms could be responsible for this finding. First, as indicated throughout this paper, the cellular disruption events associated with freezing/thawing the meat may have negated the increased moisture retention associated with EGP- and PN treatments 
320 reported by Phelps et al. (2014). This can be inferred by the fact that all treatment groups had

321 similar expressible moisture percentages prior to pumping, therefore indicating they have similar

322 water binding capacity. The second mechanism responsible for lack of moisture retention

323 differences could be that fat was added to each sample to achieve the same final fat blend. Roth

324 et al. (1999) found that reduced-fat patties possessed more water and less fat in the raw and

325 cooked state than high-fat patties. More importantly, the authors reported that cook loss

326 percentage mirrored fat content of the blend rather than water content of the blend. This would

327 indicate that water binding is more important for ground beef blends made with a lower fat

328 content, and the differences reported by Phelps et al. (2014) may have been masked by adding

329 additional fat to the lean.

\section{Conclusion}

Injection of frozen/thawed beef loins with $0.5 \%$ sodium chloride and $0.3 \%$ sodium

332 tripolyphosphate increased loin $\mathrm{pH}$ by up to 0.32 units after 7 -d of storage. As expected,

333 enhanced steaks had improved WBSF when compared to values reported by Phelps et al. (2014)

334 fresh steaks, but no large differences in WBSF were detected between dietary programs and use

335 of ExGP once steaks were enhanced. Expressible moisture analysis revealed that both before and

336 after injection, there was no differences in treatments to hold water. This finding is reflected in

337 the lack of pre-harvest treatment differences for purge loss and cook loss from ground beef and

338 enhanced steaks during cooking. Although not measured, freezing of the meat may have

339 influenced results in this study, thus warranting further investigation of the impact of freezing on

340 water holding capacity of beef from cattle supplemented PN Beef Program supplements. 


\section{Tables}

Table 1. Diets (dry basis) for steers fed conventional feedlot $\operatorname{diets}^{\dagger}$ or Alltech Programmed Nutrition Beef Program

\begin{tabular}{lcc}
\hline \hline Ingredient, \% & Conventional & Alltech \\
\hline Wet corn gluten feed & 35.00 & 35.00 \\
Steam-flaked corn & 53.55 & 53.56 \\
Ground wheat straw & 7.00 & 7.00 \\
Feed additive premix & 2.16 & - \\
Mineral/vitamin supplement & 2.29 & 2.23 \\
Programmed Nutrition supplement & - & 2.21 \\
\hline
\end{tabular}

${ }^{\dagger}$ Conventional diets included vitamin A at 2,200 IU/kg; vitamin E at $22 \mathrm{IU} / \mathrm{kg}$; copper sulfate to provide $10 \mathrm{mg} / \mathrm{kg} \mathrm{Cu}$; cobalt carbonate to provide $0.15 \mathrm{mg} / \mathrm{kg} \mathrm{Co}$; ethylenediamine dihydriodide to provide $0.5 \mathrm{mg} / \mathrm{kg}$ I; manganous sulfate to provide $60 \mathrm{mg} / \mathrm{kg} \mathrm{Mn}$; sodium selenite to provide $0.3 \mathrm{mg} / \mathrm{kg}$ Se; zinc sulfate to provide 60 $\mathrm{mg} / \mathrm{kg} \mathrm{Zn}$ on a dry matter basis; as well as $300 \mathrm{mg}^{\circ}$ animal ${ }^{-1} \cdot \mathrm{d}^{-1}$ of monensin and 90 mg・animal ${ }^{-1} \bullet \mathrm{d}^{-1}$ of tylosin (Elanco Animal Health; Greenfield, IN).

The Alltech diet included Programmed Nutrition Receiver in the total mixed ration

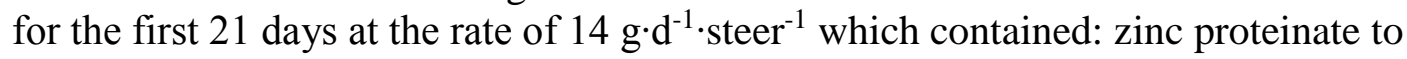
provide $10.7 \mathrm{mg} / \mathrm{kg} \mathrm{Zn}$; manganese proteinate to provide $7.1 \mathrm{mg} / \mathrm{kg}$ manganese; cobalt proteinate to provide $1.2 \mathrm{mg} / \mathrm{kg}$ cobalt; copper proteinate to provide $2.9 \mathrm{mg} / \mathrm{kg}$ copper; calcium iodate to provide $0.6 \mathrm{mg} / \mathrm{kg}$ iodine; selenium yeast to provide 0.31 $\mathrm{mg} / \mathrm{kg}$ selenium on a dry matter basis as well as ascorbic acid, Aspergillus oryzae fermentation product, Lactobacillus acidophilus fermentation product, and Enterococcus faecium fermentation product. Thereafter, Programmed Nutrition

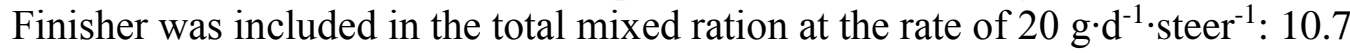
$\mathrm{mg} / \mathrm{kg} \mathrm{Zn}$; manganese proteinate to provide $7.1 \mathrm{mg} / \mathrm{kg}$ manganese; cobalt proteinate to provide $1.2 \mathrm{mg} / \mathrm{kg}$ cobalt; copper proteinate to provide $2.9 \mathrm{mg} / \mathrm{kg}$ copper; calcium iodate to provide $0.6 \mathrm{mg} / \mathrm{kg}$ iodine; selenium yeast to provide $0.31 \mathrm{mg} / \mathrm{kg}$ selenium on a dry matter basis as well as ascorbic acid, Aspergillus niger fermentation product, Lactobacillus acidophilus fermentation product, and Enterococcus faecium fermentation product. Both supplements were premixed into a ground corn carrier and subsequently blended into the total mixed ration. 
Table 2. $\mathrm{pH}$ of beef strip loins from steers of steers fed conventional diets ${ }^{\dagger}$ or Alltech Programmed Nutrition Beef Program ${ }^{*}$ with and without exogenous growth promotants ${ }^{\S}$ recorded pre-injection, post-injection, and after $7 \mathrm{~d}$ of storage.

\begin{tabular}{|c|c|c|c|c|c|c|c|c|c|c|c|c|}
\hline & \multicolumn{2}{|c|}{ Conventional } & \multicolumn{2}{|c|}{ Alltech PN } & \multirow[b]{2}{*}{ SEM } & \multicolumn{6}{|c|}{$P-$ value } & \multirow[b]{2}{*}{$\begin{array}{c}\text { Prog } \times \text { ExGP } \times \\
\text { Period }\end{array}$} \\
\hline & EGP- & EGP+ & EGP- & EGP+ & & Program & ExGP & Period & $\begin{array}{c}\text { Prog } \\
\times \text { Period }\end{array}$ & $\begin{array}{c}\text { ExGP } \times \\
\text { Period }\end{array}$ & Prog $\times$ ExGP & \\
\hline $\mathrm{pH}$ & & & & & 0.03 & 0.02 & 0.052 & $<0.01$ & 0.10 & 0.02 & 0.39 & 0.55 \\
\hline Pre-injection & 5.53 & 5.52 & 5.53 & 5.53 & & & & & & & & \\
\hline Post-injection ${ }^{1}$ & 5.85 & 5.76 & 5.93 & 5.85 & & & & & & & & \\
\hline After storage $^{2}$ & 5.86 & 5.83 & 5.85 & 5.88 & & & & & & & & \\
\hline
\end{tabular}

${ }^{\dagger}$ Conventional diets included vitamin A at 2,200 IU/kg; vitamin E at $22 \mathrm{IU} / \mathrm{kg}$; copper sulfate to provide $10 \mathrm{mg} / \mathrm{kg} \mathrm{Cu}$; cobalt carbonate to provide $0.15 \mathrm{mg} / \mathrm{kg}$ Co; ethylenediamine dihydriodide to provide $0.5 \mathrm{mg} / \mathrm{kg} \mathrm{I}$; manganous sulfate to provide $60 \mathrm{mg} / \mathrm{kg} \mathrm{Mn}$; sodium selenite to provide $0.3 \mathrm{mg} / \mathrm{kg}$ Se; zinc sulfate to provide $60 \mathrm{mg} / \mathrm{kg} \mathrm{Zn}$ on a dry matter basis; as well as $300 \mathrm{mg} \cdot \operatorname{animal}^{-1} \bullet \mathrm{d}^{-1}$ of monensin and $90 \mathrm{mg} \cdot \mathrm{animal}^{-1} \bullet \mathrm{d}^{-1}$ daily of tylosin $($ Elanco Animal Health; Greenfield, IN).

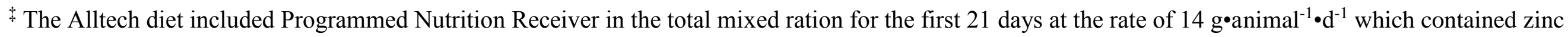
proteinate to provide $10.7 \mathrm{mg} / \mathrm{kg} \mathrm{Zn}$; manganese proteinate to provide $7.1 \mathrm{mg} / \mathrm{kg}$ manganese; cobalt proteinate to provide $1.2 \mathrm{mg} / \mathrm{kg}$ cobalt; copper proteinate to provide $2.9 \mathrm{mg} / \mathrm{kg}$ copper; calcium iodate to provide $0.6 \mathrm{mg} / \mathrm{kg}$ iodine; selenium yeast to provide $0.31 \mathrm{mg} / \mathrm{kg}$ selenium on a dry matter basis; as well as ascorbic acid, Aspergillus oryzae fermentation product, Lactobacillus acidophilus fermentation product, and Enterococcus faecium fermentation product. Thereafter, Programmed Nutrition Finisher was included in the total mixed ration at the rate of 20 g•animal ${ }^{-1} \cdot \mathrm{d}^{-1}$ which contained zinc proteinate to provide $10.7 \mathrm{mg} / \mathrm{kg} \mathrm{Zn}$; manganese proteinate to provide $7.1 \mathrm{mg} / \mathrm{kg}$ manganese; cobalt proteinate to provide $1.2 \mathrm{mg} / \mathrm{kg}$ cobalt; copper proteinate to provide $2.9 \mathrm{mg} / \mathrm{kg}$ copper; calcium iodate to provide $0.6 \mathrm{mg} / \mathrm{kg}$ iodine; selenium yeast to provide $0.31 \mathrm{mg} / \mathrm{kg}$ selenium on a dry matter basis; as well as ascorbic acid, Aspergillus niger fermentation product, Lactobacillus acidophilus fermentation product, and Enterococcus faecium fermentation product. Both supplements were premixed into a ground corn carrier and subsequently blended into the total mixed ration.

${ }^{\S}$ Exogenous growth promotants included Component ES implant administered on $\mathrm{d} 1$ of the experiment, Component TE-IS at reimplant, and ractopamine hydrochloride (Optaflexx) fed at $400 \mathrm{mg}$ /animal daily for the final $28 \mathrm{~d}$ before harvest (all products from Elanco Animal Health).

${ }^{1}$ Recorded following injection after a 2 min rest.

${ }^{2}$ Recorded after $7 \mathrm{~d}$ of storage. 
Table 3. Purge loss of injected beef Longissimus lumborum, cook loss of injected beef Longissimus steaks and ground beef, and Warner-Bratzler shear force (WBSF) from steers fed conventional diets ${ }^{\dagger}$ or Alltech Programmed Nutrition Beef Program ${ }^{\ddagger}$ with and without exogenous growth promotants ${ }^{\S}$

\begin{tabular}{|c|c|c|c|c|c|c|c|c|}
\hline \multirow[b]{2}{*}{ Item } & \multicolumn{2}{|c|}{ Conventional } & \multicolumn{2}{|c|}{ Alltech PN } & \multirow[b]{2}{*}{ SEM } & \multicolumn{3}{|c|}{$P$ - value } \\
\hline & EGP- & EGP+ & EGP- & EGP+ & & Program & ExGP & Prog $\times$ ExGP \\
\hline Purge loss ${ }^{1}, \%$ & 1.31 & 1.51 & 1.45 & 1.09 & 0.23 & 0.54 & 0.72 & 0.23 \\
\hline Steak cook loss ${ }^{2}, \%$ & 22.89 & 21.02 & 23.28 & 22.60 & 1.03 & 0.35 & 0.23 & 0.57 \\
\hline Ground beef cook loss ${ }^{2}, \%$ & 23.36 & 21.72 & 22.89 & 22.41 & 0.59 & 0.86 & 0.08 & 0.34 \\
\hline WBSF, N & 20.9 & 19.0 & 18.0 & 19.0 & 1.0 & 0.05 & 0.54 & 0.06 \\
\hline
\end{tabular}

${ }^{\dagger}$ Conventional diets included vitamin A at 2,200 IU/kg; vitamin E at $22 \mathrm{IU} / \mathrm{kg}$; copper sulfate to provide 10 $\mathrm{mg} / \mathrm{kg} \mathrm{Cu}$; cobalt carbonate to provide $0.15 \mathrm{mg} / \mathrm{kg} \mathrm{Co}$; ethylenediamine dihydriodide to provide $0.5 \mathrm{mg} / \mathrm{kg} \mathrm{I}$; manganous sulfate to provide $60 \mathrm{mg} / \mathrm{kg} \mathrm{Mn}$; sodium selenite to provide $0.3 \mathrm{mg} / \mathrm{kg} \mathrm{Se}$; zinc sulfate to provide 60 $\mathrm{mg} / \mathrm{kg} \mathrm{Zn}$ on a dry matter basis; as well as $300 \mathrm{mg} / \mathrm{animal}$ daily of monensin and $90 \mathrm{mg} / \mathrm{animal}$ daily of tylosin (Elanco Animal Health; Greenfield, IN).

$\$$ The Alltech diet included Programmed Nutrition Receiver in the total mixed ration for the first 21 days at the rate of $14 \mathrm{~g} / \mathrm{animal}$ daily which contained zinc proteinate to provide $10.7 \mathrm{mg} / \mathrm{kg} \mathrm{Zn}$; manganese proteinate to provide $7.1 \mathrm{mg} / \mathrm{kg}$ manganese; cobalt proteinate to provide $1.2 \mathrm{mg} / \mathrm{kg}$ cobalt; copper proteinate to provide 2.9 $\mathrm{mg} / \mathrm{kg}$ copper; calcium iodate to provide $0.6 \mathrm{mg} / \mathrm{kg}$ iodine; selenium yeast to provide $0.31 \mathrm{mg} / \mathrm{kg}$ selenium on a dry matter basis; as well as ascorbic acid, Aspergillus oryzae fermentation product, Lactobacillus acidophilus fermentation product, and Enterococcus faecium fermentation product. Thereafter, Programmed Nutrition Finisher was included in the total mixed ration at the rate of $20 \mathrm{~g} /$ animal daily which contained zinc proteinate to provide $10.7 \mathrm{mg} / \mathrm{kg} \mathrm{Zn}$; manganese proteinate to provide $7.1 \mathrm{mg} / \mathrm{kg}$ manganese; cobalt proteinate to provide 1.2 $\mathrm{mg} / \mathrm{kg}$ cobalt; copper proteinate to provide $2.9 \mathrm{mg} / \mathrm{kg}$ copper; calcium iodate to provide $0.6 \mathrm{mg} / \mathrm{kg}$ iodine; selenium yeast to provide $0.31 \mathrm{mg} / \mathrm{kg}$ selenium on a dry matter basis; as well as ascorbic acid, Aspergillus niger 
fermentation product, Lactobacillus acidophilus fermentation product, and Enterococcus faecium fermentation product. Both supplements were premixed into a ground corn carrier and subsequently blended into the total mixed ration.

${ }^{\S}$ Exogenous growth promotants included Component ES implant administered on $\mathrm{d} 1$ of the experiment, Component TE-IS at reimplant, and ractopamine hydrochloride (Optaflexx) fed at $400 \mathrm{mg} / \mathrm{animal}$ daily for the final $28 \mathrm{~d}$ before harvest (all products from Elanco Animal Health).

${ }^{1}[$ (pumped weight-stored weight)/pumped weight $] \times 100$.

${ }^{2}[$ (pre-cook weight-cooked weight)/pre-cook weight $] \times 100$. 
Table 4. Expressible moisture and water binding ability of beef strip loins from steers fed conventional diets ${ }^{\dagger}$ or Alltech Programmed Nutrition Beef Program $^{\ddagger}$ with and without exogenous growth promotants ${ }^{\S}$ before injection and after $7 \mathrm{~d}$ of storage.

\begin{tabular}{|c|c|c|c|c|c|c|c|c|c|c|c|c|}
\hline \multirow[b]{2}{*}{ Item } & \multicolumn{2}{|c|}{ Conventional } & \multicolumn{2}{|c|}{ Alltech PN } & \multirow[b]{2}{*}{ SEM } & \multicolumn{7}{|c|}{$P-$ value } \\
\hline & EGP- & EGP+ & EGP- & EGP+ & & Program & ExGP & Period & $\begin{array}{l}\text { Prog } x \\
\text { Period }\end{array}$ & $\begin{array}{c}\text { ExGP } \times \\
\text { Period } \\
\end{array}$ & $\begin{array}{l}\text { Prog } \times \\
\text { ExGP }\end{array}$ & $\begin{array}{c}\text { Prog } \times \text { ExGP } \times \\
\text { Period }\end{array}$ \\
\hline Expressible moisture $^{1}, \%$ & & & & & 0.76 & 0.97 & 0.90 & 0.67 & 0.99 & 0.13 & 0.84 & 0.36 \\
\hline Before injection & 11.12 & 10.03 & 10.84 & 10.36 & & & & & & & & \\
\hline After storage & 10.20 & 11.36 & 10.75 & 10.85 & & & & & & & & \\
\hline Water binding ability ${ }^{2}, \%$ & & & & & 2.05 & 0.96 & 0.21 & $<0.01$ & 0.70 & $<0.01$ & 0.50 & 0.99 \\
\hline Before injection & 19.86 & 31.64 & 20.42 & 28.88 & & & & & & & & \\
\hline After storage & 32.79 & 25.61 & 34.21 & 25.49 & & & & & & & & \\
\hline
\end{tabular}

†Conventional diets included vitamin A at 2,200 IU/kg; vitamin E at $22 \mathrm{IU} / \mathrm{kg}$; copper sulfate to provide $10 \mathrm{mg} / \mathrm{kg} \mathrm{Cu}$; cobalt carbonate to provide $0.15 \mathrm{mg} / \mathrm{kg}$ Co; ethylenediamine dihydriodide to provide $0.5 \mathrm{mg} / \mathrm{kg}$ I; manganous sulfate to provide $60 \mathrm{mg} / \mathrm{kg} \mathrm{Mn}$; sodium selenite to provide $0.3 \mathrm{mg} / \mathrm{kg}$ Se; zinc sulfate to provide $60 \mathrm{mg} / \mathrm{kg} \mathrm{Zn}$ on a dry matter basis; as well as $300 \mathrm{mg} \bullet$ animal ${ }^{-1} \bullet \mathrm{d}^{-1}$ of monensin and $90 \mathrm{mg}^{\circ}$ animal ${ }^{-1} \bullet \mathrm{d}^{-1}$ of tylosin $($ Elanco Animal Health; Greenfield, IN).

$\$$ The Alltech diet included Programmed Nutrition Receiver in the total mixed ration for the first 21 days at the rate of $14 \mathrm{~g} \bullet a n i m a l^{-1} \bullet \mathrm{d}^{-1} \mathrm{which}$ contained zinc proteinate to provide $10.7 \mathrm{mg} / \mathrm{kg} \mathrm{Zn}$; manganese proteinate to provide $7.1 \mathrm{mg} / \mathrm{kg}$ manganese; cobalt proteinate to provide $1.2 \mathrm{mg} / \mathrm{kg}$ cobalt; copper proteinate to provide $2.9 \mathrm{mg} / \mathrm{kg}$ copper; calcium iodate to provide $0.6 \mathrm{mg} / \mathrm{kg}$ iodine; selenium yeast to provide $0.31 \mathrm{mg} / \mathrm{kg}$ selenium on a dry matter basis; as well as ascorbic acid, Aspergillus oryzae fermentation product, Lactobacillus acidophilus fermentation product, and Enterococcus faecium fermentation product. Thereafter, Programmed Nutrition Finisher was included in the total mixed ration at the rate of $20 \mathrm{~g} \bullet$ animal ${ }^{-1} \bullet \mathrm{d}^{-1}$ which contained zinc proteinate to provide $10.7 \mathrm{mg} / \mathrm{kg} \mathrm{Zn}$; manganese proteinate to provide $7.1 \mathrm{mg} / \mathrm{kg}$ manganese; cobalt proteinate to provide $1.2 \mathrm{mg} / \mathrm{kg}$ cobalt; copper proteinate to provide $2.9 \mathrm{mg} / \mathrm{kg}$ copper; calcium iodate to provide $0.6 \mathrm{mg} / \mathrm{kg}$ iodine; selenium yeast to provide $0.31 \mathrm{mg} / \mathrm{kg}$ selenium on a dry matter basis; as well as ascorbic acid, Aspergillus niger fermentation product, Lactobacillus acidophilus fermentation product, and Enterococcus faecium fermentation product. Both supplements were premixed into a ground corn carrier and subsequently blended into the total mixed ration.

${ }^{\S}$ Exogenous growth promotants included Component ES implant administered on $\mathrm{d} 1$ of the experiment, Component TE-IS at reimplant, and ractopamine hydrochloride (Optaflexx) fed at $400 \mathrm{mg} / \mathrm{animal}$ daily for the final $28 \mathrm{~d}$ before harvest (all products from Elanco Animal Health).

${ }^{1}$ [(Initial weight-centrifuged weight)/initial weight] $\times 100$.

${ }^{2}$ Calculated as $300-(11.43 \times$ supernatant volume $)$. 


\section{Literature Cited}

Aberle, E. D., Forrest, J. C., Gerrard, D. E., \& Mills, E. W. (2003). Principles of meat science (4th ed.). Dubuque, IA: Kendall/Hunt Publishing Co.

AMSA. (1995). Research guidelines for cookery, sensory evaluation, and instrumental tenderness measurement of fresh meat. Centennial, CO: American Meat Science Association in cooperation with the National Livestock and Meat Board, now the National Cattleman's Beef Association.

Boles, J. A., \& Swan, J. E. (2002). Meat and storage effects on processing characteristics of beef roasts. Meat Science, 62, 121-127.

Brooks, J. C., Mehaffey, J. M., Collins, J. A., Rogers, H. R., Legako, J., Johnson B. J., Lawerenc, T, Allen, D. M., Streeter, M. N., Nichols, W. T., Hutcheson, J. P., Yates, D. A., \& Miller, M. F. (2010). Moisture enhancement and blade tenderization effects on the shear force and palatability of strip loin steaks from beef cattle fed zilpaterol hydrochloride. Journal of Animal Science, 88, 1809-1816.

Currie, R. W. \& Wolfe, F. H. (1980). Rigor related changes in mechanical properties (tensile and adhesive) and extracellular space in beef muscle. Meat Science, 4, 123-143.

Grobbel, J. P, Dikeman, M. E., Hunt, M. C., \& Milliken, G. A. (2008). Effects of different packaging methods and injection-enhancement on beef tenderness, sensory attributes, desmin degradation, and display color. Journal of Animal Science, 86, 2697-2710.

Hiner, R. L., Madsen, L. L., \& Hankins, O. G. (1945). Histological characteristics, tenderness, and drip losses of beef in relation to temperature of freezing. Journal of Food Science, $10,312-324$. 
Hocquette, J., Botreau, R., Picard, B., Alain, J., Pethick, D. W., \& Scollan, N. D. (2012).

Opportunities for predicting and manipulating beef quality. Meat Science, 92, 197-209.

Honikel, K. O. (2004). Water-holding capacity of meat. M. F. W. te Pas, M. E. Everts, \& H. P. Haagsman (Eds.), Muscle Development of Livestock Animals (pp. 389-400). Cambridge, MA: CABI Publishing.

Huff-Lonergan, E. and Lonergan, S. M. (2005). Mechanisms of water-holding capacity of meat: The role of postmortem biochemical and structural changes. Meat Science, 71, 194-204.

Jauregui, C. A., Regenstein, J. M., \& Baker, R. C. (1981). A simple centrifugal method for measuring expressible moisture, a water-binding property of muscle foods. Journal of Food Science, 46, 1271.

McGee, M. R., Henry, K .L., Brooks, J. C., Ray, F. K., \& Morgan, J. B. (2003). Injection of sodium chloride, sodium tripolyphosphate, and sodium lactate improves Warner-Bratzler shear and sensory characteristics of pre-cooked inside round roasts. Meat Science, 64, 273-277.

Miller, M. F., Carr, M. A., Ramsey, C. B., Crockett, K. L., \& Hoover, L. C. (2001). Consumer thresholds for establishing the value of beef tenderness. Journal of Animal Science, 79, 3062-3068.

Molina, M. E., Johnson, D. D., West, R. L., \& Gwartney, B. L. (2005). Enhancing palatability traits in beef chuck muscles. Meat Science, 71, 52-61.

Offer, G. \& Trinick, J. (1983). On the mechanism of water holding in meat: the swelling and shrinking of myofibrils. Meat Science, 8, 245-281. 
Offer, G., Knight, P., Jeacoke, R., Almond, R., Cousins, T., Elsey, J., Parsons, N., Sharp, A., Starr, R., \& Purslow, P. (1989). The structural basis of the water-holding, appearance and toughness of meat and meat products. Food Microstructure, 8, 151-170.

O’Quinn, T. G., Brooks, J. C., Polkinghorne, R. J., Garmyn, A. J., Johnson, B. J., Starkey, J. D., Rathmann, R. J., \& M. F. Miller. (2012). Consumer assessment of beef strip loin steaks of varying fat levels. Journal of Animal Science, 90, 626-634.

Phelps, K. J., Drouillard, J. S., Jennings, J. S., Depenbusch, B. E., Van Bibber-Krueger, C. L., Miller, K. A., Vaughn, M. A., Burnett, D. D., Ebarb, S. M., Houser, T. A., Johnson, S. E., \& Gonzalez, J. M. (2014). Effects of the PN Beef Program on meat quality characteristics. Journal of Animal Science, 92, 1780-1791.

Pietrasik, J., \& Janz, J. A. M. (2009). Influence of freezing and thawing on the hydration characteristics, quality, and consumer acceptance of whole muscle beef injected with solutions of salt and phosphate. Meat Science, 81, 523-532.

Pietrasik, Z., Dhanda, J. S., Shand, P. J., \& Pegg, R. B. (2006). Influence of injection, packaging, and storage conditions on the quality of beef and bison steaks. Journal of Food Science, $71,110-118$.

Pietrasik, Z., \& Shand, P. J. (2005). Effects of mechanical tenderization and moisture enhancement on the processing characteristics and tenderness of beef semimembranosus roasts. Meat Science, 71, 498-505. 
Platter, W. J., Tatum, J. D., Belk, K. E., Scanga, J. A., \& Smith, G. C. (2003). Effects of repetitive use of hormonal implants on beef carcass quality, tenderness, and consumer ratings of beef palatability. Journal of Animal Science, 81, 984-996.

Polymenidis, A. (1978). Chilling and freezing meat. Fleischwirtschaft, 58, 728-732.

Robbins, K., Jensen, J., Ryan, K. J., Homco-Ryan, C., McKeith, F. K., \& Brewer, M. S. (2002). Enhancement effects on sensory and retail display characteristics of beef round. Journal of Muscle Foods, 13, 279-288.

Roth, D. M., McKeith, F. K., \& Brewer, M. S. (1999). Processing parameter effects on sensory and instrumental texture characteristics of reduced-fat ground beef patties. Journal of Muscle Foods, 10, 163-176.

Shanks, B. C., Wulf, D. M., \& Maddock, R. J. (2002). Technical note: The effect of freezing on Warner-Bratzler shear force values of beef longissimus steaks across several postmortem aging periods. Journal of Animal Science, 80, 2122-2125.

Smith, L. A., Simmons, S. L., McKeith, F. K., Bechtel, P. J., \& Brady, P. L. (1984). Effects of sodium tripolyphosphate on physical and sensory properties of beef and pork roasts. Journal of Food Science, 49, 1636-1637. 1641.

Wicklund, S. E., Homco-Ryan, C., Ryan, K. J., McKeith, F. K., McFarlane, B. J., \& Brewer, M. S. (2005). Aging and enhancement effects on quality characteristics of beef strip steaks. Journal of Food Science, 70, 242-248.

Winger, R. J., \& Hagyard, C. J. (1994). Juiciness- its importance and some contributing factors. In A. M. Pearson, \& T. R. Dutson (Eds.), Quality attributes and their measurement in 
meat, poultry, and fish products: Advances in meat research (pp. 94-124). New York: Perseus Books Group.

Winterholler, S. J., Parsons, G. L., Walker, D. K., Quinn, M. J., Drouillard, J. S., \& Johnson, B. J. (2008). Effect of management system on response to ractopamine- $\mathrm{HCl}$ in yearling steers. Journal of Animal Science, 86, 2401-2414. 